\title{
A Critical Examination of Geoengineering: Economic and Technological Rationality in Social Context
}

\author{
Ryan Gunderson ${ }^{1}$ * , Brian Petersen ${ }^{2}$ and Diana Stuart ${ }^{3}$ \\ 1 Department of Sociology and Gerontology, Miami University, Oxford, OH 45056, USA \\ 2 Department of Geography, Planning and Recreation, Program in Sustainable Communities, \\ Northern Arizona University, Flagstaff, AZ 86011, USA; brian.petersen@nau.edu \\ 3 School of Earth Sciences and Sustainability, Program in Sustainable Communities, \\ Northern Arizona University, Flagstaff, AZ 86011, USA; diana.stuart@nau.edu \\ * Correspondence: gunderrm@miamioh.edu; Tel.: +1-513-529-4113
}

Received: 20 November 2017; Accepted: 17 January 2018; Published: 20 January 2018

\begin{abstract}
Geoengineering — specifically stratospheric aerosol injection-is not only risky, but supports powerful economic interests, protects an inherently ecologically harmful social formation, relegates the fundamental social-structural changes needed to address climate change, and is rooted in a vision of a nature as a set of passive resources that can be fully controlled in line with the demands of capital. The case for geoengineering is incomprehensible without analyzing the social context that gave birth to it: capitalism's inability to overcome a contradiction between the need to accumulate capital, on the one hand, and the need to maintain a stable climate system on the other. Substantial emissions reductions, unlike geoengineering, are costly, rely more on social-structural than technical changes, and are at odds with the current social order. Because of this, geoengineering will increasingly be considered a core response to climate change. In light of Herbert Marcuse's critical theory, the promotion of geoengineering as a market-friendly and high-tech strategy is shown to reflect a society that cannot set substantive aims through reason and transforms what should be considered means (technology and economic production) into ends themselves. Such a condition echoes the first-generation Frankfurt School's central thesis: instrumental rationality remains irrational.
\end{abstract}

Keywords: climate engineering; environmental sociology; critical theory; science and technology studies; solar radiation management; carbon dioxide removal; Marcuse; stratospheric sulfate injection; stratospheric aerosol injection; albedo modification

\section{Introduction}

"[A]dvanced industrial society is ... the latest stage in the realization of a specific historical project—namely, the experience, transformation, and organization of nature as the mere stuff of domination.... In the medium of technology, culture, politics, and the economy merge into an omnipresent system which swallows up or repulses all alternatives."

-Herbert Marcuse [1] (p. xvi)

On the one hand, the puzzle of geoengineering, climate engineering, or "climate intervention"- " the deliberate large-scale intervention in the Earth's climate system, in order to moderate global warming" [2] (p. ix) —entails a series of seemingly purely technical questions concerning effectiveness, affordability, timeliness, and safety. For instance, while the Royal Society's [2] influential assessment of geoengineering methods addressed substantive questions of ethics and governance - in a rather brief, abstract, and problematic way [3] — the criteria for assessing proposed strategies were based solely on seemingly purely technical criteria (i.e., effectiveness, affordability, timeliness, and safety). In a systematic analysis of geoengineering appraisals, Bellamy et al. [4] found 
that all appraisals framed the problem in narrow, mostly technical terms and most commonly as an issue of climate change emergency conditions, insufficient mitigation efforts, or climate change impacts. In a recent report on "albedo modification" (see "Solar Radiation Management" in Section 3), the U.S. National Research Council [5] (p. 186) were clear that "[a]ny future decisions surrounding the use of albedo modification will need to be based on more than just scientific theories" and must address "social, ethical, political, and legal discussions" along with technical considerations.

While we address the serious potential risks of geoengineering, we also ask, in the spirit of a form of rationality capable of addressing both means and ends, why geoengineering is offered as a climate change solution: What structural forces and forms of rationality have driven the recent agenda for geoengineering? The "whys" are not as straightforward as expert-analytic appraisals suggest. In the aforementioned study, the "obvious exclusions" in the context frames included a wealth of social and ethical issues [4] (p. 605). However, recent analyses of geoengineering have asked substantive questions about geoengineering: its social, legal, political, and ethical dimensions (e.g., [3,5-26]).

We adopt a method of "ideology critique," which, in social-ecological context, entails "immanent critique" (explained shortly), historicizing seemingly natural and immutable social conditions, and diagnosing socio-ecological contradictions and crises [27]. Horkheimer [28] (p. 173) summarized immanent critique as "apprais[ing] society by the light of the very ideas that it recognizes as its highest values" with an awareness "that these ideas reflect the taints of reality" (see also [29]). In the context of geoengineering, to paraphrase Horkheimer, we appraise geoengineering "by the light of the very ideas that it recognizes as its highest values" with awareness that geoengineering strategies reflect a social formation that probably cannot overcome a contradiction between the need to accumulate capital, on the one hand, and the need to maintain a stable climate system on the other (see Section 4.1). Because reasons to support geoengineering are primarily technical and means-based, our assessment is akin to the post-Second World War ideas of the first-generation Frankfurt School, in which immanent critique took the form of a critique of instrumental reason as "unreason" [30]. Our examination has much in common with Clive Hamilton's [31] (p. 53) argument that "what matters ethically about geoengineering is not only the outcome but also the human disposition it reveals" (see also [32,33]). By attending to both the social-structural conditions that gave birth to the geoengineering agenda and the forms of rationality used to legitimate it, we diagnose what geoengineering means for human rationality in capitalist society and the chance for social alternatives. Our central contribution is bringing together sociological questions concerning the relationship between social structure and patterns of thinking with substantive questions regarding the desirability of geoengineering.

We draw on the early Frankfurt School's theorization of technology to examine which structural forces and forms of rationality have driven the recent agenda for geoengineering in advanced capitalist societies. We focus particularly on the work of Herbert Marcuse for a perspective that is neither technophobic nor naively Promethean. Although too easily cast aside as deterministic, gloomy, and monolithic, the epigraph, written over five decades ago in Marcuse's most celebrated and infamous work, foretells the story of geoengineering. It presupposes the necessary categories and causal frameworks for understanding why putting giant mirrors into space or intentionally manufacturing large-scale algal blooms are beginning to be considered less utopian means to address climate change than reducing greenhouse gas (GHG) emissions. Like Feenberg (e.g., [34,35]), we see Marcuse's theory as one possessing both a critical conception of the social and environmental implications of technology as well as a potential solution to the destructive consequences of technical achievements (see Section 2.2).

In the following, we review environmental social-scientific, STS, and ethical work on geoengineering, focusing on what is known about conceptualizations used to frame geoengineering (Section 2.1), and then integrate Marcuse's writings on technology and abridge Feenberg's explication (Section 2.2). Following an overview of stratospheric aerosol injection and its risks (Section 3), we examine how a Marcusian perspective can explain the structural forces and forms of rationality that have driven the recent agenda for geoengineering in advanced capitalist societies (Section 4). In the 
conclusion, we predict that geoengineering will increasing be considered a leading strategy to combat climate change, and that the prospect of the deployment of potentially catastrophic geoengineering strategies substantiates the first-generation Frankfurt School's bleakest assessments of instrumental rationality (Section 5).

\section{The Social Dimensions of Geoengineering: Revisiting Marcuse}

\subsection{A Review of the Social Dimensions of Geoengineering: What the Frankfurt School Can Offer}

A growing number of environmental social scientists, STS scholars, environmental ethicists, and others have developed nuanced positions concerning the social, political, legal, and ethical dimensions of geoengineering, including evaluations of geoengineering based on its unanticipated harms and inherent wrongness, and investigating options for geoengineering governance and the issue of consent (e.g., $[3,5-26,31,33])$. Social scientific research has given special attention to public perceptions of geoengineering [16,36-39] and, especially relevant to this project, media and expert framings of geoengineering $[4,11,40-44]$.

In an analysis of newspaper articles (cf. $[43,44]$ ), and lending support to the argument that technological rationality underpins the geoengineering agenda (see Section 4.2), Nerlich and Jespal [40] found that various metaphors used to frame geoengineering "can all be related to one conceptual master metaphor or master frame according to which the earth is a machine or cybernetic system (car, heating system, computer) that is broken but can be fix" [40] (p. 141). Two other "master-metaphors" employed to frame geoengineering included the planet as (1) a body and as (2) a patient/addict. We return to dominant media framings of geoengineering in Section 4.2, arguing that many framings of geoengineering are constituted by a form of thinking that reduces the universe to a mass storehouse of goods and services that can be easily, successfully, and wholly dominated for human aims (technological rationality).

In an analysis of assessments of geoengineering (cf. [42]), two dominant frames were identified: (1) geoengineering as a response to "insufficient mitigation" (reducing GHG emissions will not be enough to address climate change) and (2) geoengineering as a response to a "climatic emergency" [41] (see also [4]). Both of these frames are regularly invoked to make the case for geoengineering as "Plan $B$, , "[t] he dominant narrative surrounding geoengineering" [37] (p. 945), or, that geoengineering research should be conducted now because geoengineering may be necessary in a climatic emergency following insufficient GHG emissions reductions. Similarly, Sikka [11] critically analyzed discursive frames and strategies employed by those associated with pro-geoengineering think tanks. In addition to several forms of an "exceptionalism" frame, the other frame discussed by Sikka lends support to arguments more fully discussed in Section 4.1: geoengineering proponents commonly justify geoengineering proposals through appeals to the market.

Muraca and Neuber [45] advanced social-scientific and substantive examinations of geoengineering by evaluating geoengineering strategies—including stratospheric aerosol injection (discussed below) - from the perspective of criteria related to the social and intellectual movement of "degrowth". Emerging as a political slogan in France and quickly developing into an "activist-led science" [46], degrowth refers to "socially sustainable and equitable reduction of society's throughput" [47] (p. 59) (for review, see [48]). Afforestation under certain conditions may be the only geoengineering strategy compatible with a degrowth perspective, one developed from a normative operationalization of Georgescu-Roegen's [49] concept of "viable" technology and Illich's [50] concept of a "convivial" tool. In agreement with the argument presented in Section 4.1, Muraca and Neuber [45] begin with the case that growth-dependent economies are unsustainable in the long-run. They develop a unique rendition of the "moral hazard" case against geoengineering [51] from a degrowth perspective: in a growth-dependent society, geoengineering deployment will create trade-offs with mitigation efforts, thereby delaying the transition to an ecological society (see also [52]). 
We further elevate analyses of the social dimensions of geoengineering by examining structural forces and forms of rationality that have driven the recent agenda for geoengineering. Despite the merits of the research discussed above, no analysis to date has sought to explain both the social-structural conditions that gave birth to the geoengineering agenda and the forms of rationality adopted to legitimate it. In relation to research on the framing of geoengineering, "forms of rationality" can be thought of as the underlying reasons why "some aspects of a perceived reality" are made "more salient" [53] (p. 52). According to the Frankfurt School, modern societies are characterized by the prevalence of a "subjective," "formal," or "instrumental" rationality, or "the ability to calculate probabilities and thereby to co-ordinate the right means with a given end" [28] (p. 5). Paradoxically, the instrumentalization of reason purges moral and aesthetic reflection from rationality, making rational judgment on the rightness of the "given end" impossible. We argue that the case for geoengineering is founded on two mutually reinforcing forms of instrumentality: economic and technological rationality. To be clear, our argument is not that economic and technological justifications for geoengineering are the only justifications, though, as shown in the literature above, economic and technological justifications are dominant modes of legitimation in the geoengineering agenda. We focus on economic and technological legitimations of geoengineering because we think these will register as the most valid and relevant justifications in policy-making and appeal to (a historically contingent) "commonsense". We make the case that the prominence, validity, and relevance of these arguments can only be understood in a particular and contradictory social context.

A second contribution of this project is connecting the forms of rationality justifying geoengineering to social-structural conditions. Attending to both social structure and political economy, on the one hand, and reasons-giving, framing, and other ideational variables, on the other, is important in the context of geoengineering. For example, we agree that geoengineering proponents have "focused on a single operational criterion (market efficiency, the economy) at the expense of all others" [11] (p. 172) (see Section 4.1) and that the earth is conceptualized as a giant machine-like entity in discussions of geoengineering [40] (see Section 4.2), but the social-structural context that makes these lines of argumentation and conceptualization central to geoengineering proponents should be made explicit.

In the next subsection, we explain why Marcuse's theory of technology is well-positioned to accomplish these tasks. In an article concerning geoengineering governance that draws from Feenberg's critical theory of technology (see Section 2.2), Sikka [12] (p. 113) hinted at what a Marcusian analysis of geoengineering can bring to the literature: "geoengineering can be seen as a dehumanizing and dangerous kind of technology created solely as a potential technical means for mitigating climate change without sacrificing our existing way of life". This article significantly expands on the latter claim through a critical examination of the structural forces and forms of rationality that have driven forward the recent agenda for geoengineering.

\subsection{The Critical Theory of Technology}

Before discussing Marcuse's theorization of technology and its relation to nature, it is helpful to contextualize these insights in his overarching critical theory of advanced capitalism and the project of critical theory itself. Critical theory requires a distinction between two interrelated dimensions: "appearance" (sometimes "existence" or "actuality") and "essence" (sometimes "potentiality") ([54,55], [56] pp. 224ff). In Marcuse, "appearance" signifies the established social-economic and political order and ossified social relations formed in the past that are thrust upon living individuals as experienced in the matter-of-fact world we find ourselves in everyday life, whereas "essence" signifies what is possible or potential in the current order's level of development, presently inhibited-yet attainable in modified conditions-hopes, needs, aims, and longings of humans, social movements to rationally alter the established order, as well as the underlying total social process that shapes the social order. There is a "tension between potentiality [essence] and actuality [appearance], between what men and things could be [essence] and what they are in fact [appearance]" [54] (p. 69). The purpose of critical theory is to bring these antagonisms to consciousness via analysis and assessment with the goal 
of helping more rational historical possibilities become existent—or to at least explain what restricts social alternatives.

Marcuse's analysis of monopoly-consumer capitalism detailed how human longings, desires, and instincts are repressed and sublimated into alienated work [57] and how advances in information and communication technologies, embedded in consumer capitalism, make possible new forms of social control [1] (for summary, see [58], pp. 136f). The most pernicious development in advanced industrial society is the manufacturing and satisfaction of "false needs," forming the widespread illusory impression that the hopes and desires of humans are already realized via mass consumption. Humans are manipulated, in part by interaction with various forms of technology, into affirmatively accepting "the way things are". By "flattening out" the tension between "the given [appearance] and the possible [essence]," some capitalist technological artifacts help to conceal underlying contradictions, i.e., function as ideology [1] (p. 8). To oversimplify Marcuse's assessment of "one-dimensionality": consumer society and its techniques allow for a smoother reproduction of the expansion of the accumulation process by fashioning automotive-like passive consumer-workers who believe "non-conformity" to be "socially useless" [1] (p. 2). Marcuse's critique of advanced capitalism, coupled with the backdrop of the Frankfurt School's philosophy of history (discussed next), is the context in which he fashions his theory of technology.

The Frankfurt School argued that the historical project of using reason to dominate nature and free humanity from nature's supremacy, a project rooted in antiquity but taking full form in the modern era, had paradoxically enslaved human beings along with the rest of nature $[59,60]$. What is considered progress in Western civilization "runs in a single strand, on the rails of the mere domination of nature" [61] (p. 212), an instrumental rationality "reproduced" in society and the self. With the proliferation of an instrumental reason incapable of formulating substantively rational ends, the development and spread of capitalism, and unreflective technical progress, reason has lost its aim (the emancipation of human beings). Marcuse's central contribution to the Frankfurt School's domination of nature thesis was his analysis and critique of modern technology. Marcuse [62] (pp. 138-139) conceptualized technology broadly, as the totality of late capitalist social organization, artifacts (instruments/machinery), as well as the modern mode of instrumental thinking. Technology is mediated by society and vice versa. Technical achievements reinforce and alter the way in which domination takes place in social relations and between society and nature, and the interests and values of society are embodied in technical achievements. This process also influences how the interests and values of society are embodied in technical achievements and even individual technical artifacts: "the machine, the instrument, does not exist outside an ensemble, a technological totality; it exists only as an element of technicity," whereby, "domination is transferred to machines and directed against nature" [63] (pp. 123, 127).

Technology transforms nature into a mechanical and infinitely malleable order for the aims of capital. This transformation of reality into a "calculable order" is underpinned by a "technological rationality," a "pure" instrumentality incapable of formulating substantive end goals [1] (p. 158), [63]. If modern science and technology, as embedded social projects, have transformed the world into a world of means, they, by definition, depend on ends. However, devoid of substantive goals that cannot be rationally formulated-instrumental reason is not concerned with the quality of ends, only with the effectiveness of means-ends are instead formulated by the "pregiven empirical reality" [64] (p. 152), or, "in line with the prevalent interests in the respective society" [65] (p. 44). Science and technology are not independent, neutral forces, but are organized in capitalist societies—their pregiven reality-to serve the interests of capital [66].

No one has done more to explicate and update Marcuse's critical account of technology than Feenberg [34,35,67-69]. Feenberg stressed two contributions of Marcuse that are especially important for this project: (1) identifying how a supposedly neutral technology "incorporates" social values and interests and (2) explaining how a supposedly neutral and formal technological rationality serves to reproduce an exploitative social order. We discuss both contributions in turn. 
Drawing from Marcuse, Feenberg's critical theory of technology holds that technology is value-laden, as opposed to value-neutral [68]. In particular, Marcuse [1,70] argued many technologies are fastened to the interests of capital. Economic rationality and its central goal of profit-maximization often shape the design and implementation of technology. Techniques and machines are used to dominate the external world due to the "presence" of ruling interests "in" them, determining "their number, their life span, their power, their place in life, and the need for them" [71] (p. 12). Translating Marcuse's argument into STS lexicon: "design embodies only a subset of the values circulating in society at any given time" and capitalism is unique in that the range of possible value-mediations of technology are reduced due to "conflict[s] with a narrow pecuniary interest" [35] (p. 105). In short, embedded in a society of organized domination, technology is often utilized to further the domination of nature and humans: "[t]echnology is always a historical-social project: in it is projected what a society and its ruling interests intend to do with men and things" [72] (pp. 223-224).

Regarding Marcuse's notion of technological rationality as explicated in Feenberg's critical theory of technology, technological reason is said to be repressive and ideological because it is unable to identify social alternatives in the existing order. Exemplifying one-dimensional thinking, modern technological rationality only "aims at classification, quantification, and control," declares that the "empirically observed thing is the only reality" (i.e., cannot detect alternative social futures within the present) [35] (p. 87), and sees nature as "stuff of control and organization" [1] (p. 153). Because technological rationality is incapable of identifying social alternatives to an exploitative and contradictory social order-an ideology capable of "hardly say[ing] more than things are the way they are" [73] (p. 202) - it contributes to the maintenance and reproduction of the social order. Stated differently, technological rationality molds all social and environmental problems into technological problems requiring technological solutions, because this mode of thinking is blind to what is possible given different social conditions.

Marcuse argued that the progressive ends of science and technology have been lost amid the means-oriented and "neutral" scientific project. Although science has become a "pillar of the established institutions and policies" in reality, the individual scientist may wrongly think they are "the dissociated withdrawn researcher" [74] (p. 158). In other words, the techno-scientific project is one-sidedly concerned with "how" questions-impressed and captivated by the achievements of scientific progress-without reflecting on the sometimes destructive ends it serves.

Exploring the social dimensions of technology and the technological dimensions of society through the critical tradition illuminates aspects of what is and what is possible in ways that major contemporary approaches in STS, such as actor-network theory, may miss. By directing analyses of the social-technological-environmental interface toward undesirable power relations and social inequalities produced by the basic processes of capitalism - an abstract category rejected by radically empirical and micro-sociological "posthuman" approaches to STS-a critical approach is better positioned to grasp, expose, and, thus, potentially overcome undesirable power relations, inequality, and environmental harm [75]. In the case of geoengineering, a Marcusian perspective highlights the interests and structure of capital and instrumental rationality in the geoengineering agenda. We acknowledge that any theory is partial, however. One potential disadvantage of the critical theory tradition for STS, as admitted by Hornborg [75] (p. 101), is contentment in abstraction and lack of attention to concrete social relations and artifacts, a limitation we hope to avoid in our critique of geoengineering. Despite the differences between critical theory and contemporary strands of STS, Feenberg [67] (p. 46) commended STS scholars for lending empirical support to Marcuse's argument that technological artifacts do, in fact, incorporate social values, or, the stance that "technology is social in much the same way as law or education or medicine insofar as it is similarly influenced by interests and public processes" (see also [35] (pp. 103ff)).

Marcuse's and Feenberg's work on the relationship between technology and capitalism opens up space for analyzing proposed geoengineering strategies as dangerous and contradictory technologies to further the domination of nature for the aims of capital's self-expansion and self-accumulation. 
Drawing from Marcuse and Feenberg, we argue that economic rationality and technological rationality are mutually reinforcing in justifying the possible deployment of geoengineering. After discussing geoengineering and risks in Section 3, we examine the role of economic rationality (Section 4.1) and technological rationality (Section 4.2) in legitimating the potential deployment of geoengineering.

\section{Geoengineering: A Technological Solution to Climate Change}

\subsection{Geoengineering}

While climate change projections portend dramatic and lasting consequences well into the future [76], global efforts to reduce emissions and limit warming have thus far failed. This has led some scientists to call for more aggressive actions to reduce GHG emissions, including a target to reduce atmospheric carbon dioxide levels to $350 \mathrm{ppm}$ [77]. The failure of the international community to commit to binding targets to reduce emissions coupled with existing and projected consequences have led to increasing arguments that geoengineering is a global necessity [78-81]. Even the latest Intergovernmental Panel on Climate Change (IPCC) [76] assessment discusses geoengineering strategies and their potential to reduce the impacts of climate change. Paul Crutzen, in his influential 2006 article in Climatic Change [64], advocated the need to research geoengineering in earnest and in doing so established geoengineering as a legitimate course of action that demanded attention. However, geoengineering has a much longer history, preceded by an even longer history of attempts to control and master the weather and climate [82].

The IPCC defines geoengineering as, "a broad set of methods and technologies that aim to deliberately alter the climate system in order to alleviate impacts of climate change" [83]. Scientists have proposed a range of geoengineering approaches that fall into two general categories: Solar Radiation Management (SRM), or, "albedo modification" [5], and Carbon Dioxide Removal (CDR) [22]. While we touch on a range of geoengineering strategies, our focus is the most widely discussed SRM option: stratospheric aerosol injection (SAI). We selected SAI for analysis because it is the only proposed SRM strategy that is considered low-cost and with high potential to prevent warming $[2,84]$. A second reason for selecting SAI is it is considered highly risky [2,5], providing an ideal entry point for addressing our underpinning research question: What structural forces and forms of rationality have driven the recent agenda for geoengineering?

SAI, the strategy put forth by Crutzen [78], is "[o]ften heralded as the most promising solar geoengineering proposal in terms of their effectiveness" [4] (p. 600). Volcanic eruptions have provided a way to assess the effect sulfur particles in the atmosphere have on incoming solar radiation and global temperature. The Mt. Pinatubo eruption in 1991 led to dimming that cooled the earth by $0.5^{\circ} \mathrm{C}$ for a year [85]. Injecting sulfur particles (sulfur dioxide, hydrogen sulfide, sulfuric acid) into the atmosphere represents an attempt to emulate this process. Sulfate aerosols can be put into the stratosphere by release from planes, balloons, or ground canons. Once in the atmosphere, the particles combine with dust and water, creating aerosols that increase atmospheric albedo. Aerosols would likely last for about one year; therefore, this strategy requires continued sulfate deposition [81]. Model results suggest that this approach may be very effective, locally and globally, and it continues to garner the most attention in terms of the number of scientific studies [86]—-many of which are examining different types of particles that could be injected into the stratosphere [87].

\subsection{Risks of Geoengineering}

"I think [geoengineering] may be infinitely more dangerous than climate change, largely due to the suspicion and social disruption it would trigger by changing humanity's relationship to nature."

-James Fleming (quoted in [88])

There are a number of risks associated with SRM in general and SAI in particular. It remains unclear how SRM may affect weather patterns, especially precipitation and therefore ecological 
and agricultural systems [89,90]. A modeling study supports previous results, indicating that the pumping of sulfate aerosols into the stratosphere may result in drought in South America, Asia, and Africa, assuming a $4{ }^{\circ} \mathrm{C}$ temperature rise would be compensated via SAI [91]. As stated by a leading geoengineering scientist: "used recklessly, geoengineering could threaten billions with starvation" [81] (p. 58). However, Keith and MacMartin [90] argued that this not need be the case: impacts and risks will depend on how SRM is deployed. Others have highlighted how sulfate aerosols do nothing to address ocean acidification and could exacerbate the ozone hole problem, increase acid rain and air pollution, have unknown impacts on plants and clouds, and reduce radiation for solar power-in addition to risks associated with human error, commercial control, and military use $[83,84,86,92,93]$. Lastly, there are serious concerns about risks to human health [94,95].

Perhaps the gravest risk associated with SRM, including SAI, because it only "masks the problem" [5] (p. 145), relates to continued carbon emissions. SRM could reduce incoming solar radiation, allowing for continued GHG emissions. If the intervention works initially but falters, or if the project cannot be maintained, temperatures could increase rapidly due to a buildup of background GHG emissions, a risk known as the "termination effect". A modeling study found that implementing SRM for 25 years and then stopping could abruptly increase temperatures by $4{ }^{\circ} \mathrm{C}$, with severe impacts on agriculture and biodiversity [96]. Scientists have warned that political instability could abruptly halt SRM and result in a rapid temperature spike [79]. As a leading scientist who supports this approach acknowledges, SRM is "a powerful and frightening tool" [81] (p. 67).

As so much of what is understood is currently based on models, many risks related to geoengineering will remain unknown unless or until the strategies are implemented. The inherent uncertainty and ignorance related to geoengineering science makes it incredibly risky. Given the vast number of unknowns, many scientists continue to question how we can engineer a system we still do not understand $[79,80]$. The possible risks and the extent of unknowns associated with geoengineering bring to the forefront the question: What structural forces and forms of rationality have driven the recent agenda for geoengineering?

Scientists, scholars, and policy-makers continue to debate supporting geoengineering research apart from the intention of implementing geoengineering. Some researchers may wish to develop SRM or CDR technologies, for the sake of science, without the intent to modify the Earth's climate. Others argue that a Plan B is critical: as the impacts of climate change become more severe, geoengineering may represent the only way to dampen the impacts and save lives [81]. Long and others [97] contended that we need research to understand the full risks and benefits of geoengineering so that we can decide whether or not to proceed with geoengineering strategies. In contrast, Hamilton [98] (p. 139) argued, "No, we should not just 'at least do the research'," citing a number of ethical and governance issues. He referred to the divide over atomic weapons research and pointed out that, "it would be naïve of researchers to imagine they can isolate themselves in a cocoon of scientific neutrality, nor can they absolve themselves of responsibility for how their schemes might be used or misused in the future" [32] (p. 21).

Some researchers, however, now clearly support eventual deployment. David Keith, the leading proponent of SRM research, advocated for research only until his 2013 book, in which he discusses specific routes for eventual SRM deployment and calls it cheap and easy [81]. Long and others [97] (p. 30) called for government funding to support climate engineering research, stating that "calls for intervention may grow" and it is critical to start with small-scale experiments immediately and make research transparent and for the public good. However, Stilgoe [99] warned that as geoengineering becomes a legitimate scientific field, controversy around research becomes neutralized and the technology becomes deterministic. Although we sometimes analyze arguments used to justify geoengineering research, the remainder of this article focuses on reasons given for possible deployment. We explore how the work of Marcuse can reveal insights regarding the role of capital, ideas about mastery and domination, and instrumental rationality in the major arguments for eventual deployment. 
It should be noted that while many scientists and scholars have opinions on deployment, we focus on some of the most vocal proponents of geoengineering.

\section{Drivers of the Geoengineering Agenda: Instrumental Rationality and Social Context}

\subsection{Geoengineering Is the Economically Rational Choice}

"[M]an encounters nature as transformed by society, subjected to a specific rationality which became, to an ever-increasing extent, technological, instrumentalist rationality, bent to the requirements of capitalism."

-Herbert Marcuse [70] (pp. 59-60)

The political-economic context that gave rise to geoengineering strategies is best understood as a contradiction between capital's need to accumulate and expand, on the one hand, and the destructive effects expansionistic production has on the conditions of production, specifically the climate system, on the other [100-102]. We agree with Weis [100] (pp. 318-319) that, "[t]he failure to account for the atmospheric burden associated with fossil energy, and its impact on the Earth's climate system, represents one of the most fundamental biophysical contradictions of industrial capitalism". The capital-climate contradiction is a monumental rendition of O'Connor's [103] (p. 162) "second contradiction of capitalism," whereby "individual capitals defend or restore profits by strategies that degrade or fail to maintain over time the material conditions of their own production". In other words, capital's drive to self-accumulate may undermine its ability to do so by destabilizing a massive condition of production (i.e., the climate system). Thus, the capital-climate contradiction represents a "creative self-destruction" [101]. This contradiction is built into the fundamental processes that characterize capitalism. "Treadmill of production" theory posits that capitalist economies must constantly expand production, creating a production cycle (a "treadmill") that increases energy and resource throughput ("withdrawals") and "additions" (pollution) into the environment [104,105], a perspective that has been reiterated in relation to climate change in various ways [106] (pp. 352-357). Work in political ecology highlights how environmental problems can be traced (through chains of explanation) to larger-scale economic relationships that prioritize capital accumulation and further contradictions (e.g., [107-109]).

The problem of climate change is clearly linked to economic growth. Macro-level empirical research and projections show that economic growth is a major driver of GHG emissions and continued economic growth is antithetical to substantial emissions reductions (e.g., [110,111]; for summary of findings concerning economic growth and resource use in general, see [112], pp. 5ff). As summarized by Hickel [113] for a popular audience, "we're only using fossil fuels in the first place to fuel the broader imperative of GDP growth. The root problem is the fact that our economic system demands ever-increasing levels of extraction, production and consumption". Marcuse [70] (p. 61) recognized these general trends early on: "it is obvious to what extent the violation of nature is inseparable from the economy of capitalism". Capitalism remains the root driver of climate change.

Capitalist societies have responded to the capital-climate contradiction in a number of ways. One response popular in the United States is to deny the reality and/or severity of anthropogenic climate change, a response sold to the public by a powerful coalition of fossil fuel industries, conservative think tanks and politicians, contrarian scientists, and other actors [114]. Less pathological responses than outright denial include establishing carbon markets, various energy efficiency measures, and the expansion of renewable energy. The increasingly popular climate policy frame of "green growth" [115,116]—alternatively, the "green economy" [117] or the "green transition" [118]—combines the greening of technology and markets in a coherent and appealing narrative and approaches climate mitigation as a capital accumulation strategy, highlighting the economic benefits of environmental protection and the supposed "synergies" between environmental protection and economic growth (for sympathetic overview, see [116]; for critical accounts, see [119]). However, carbon markets (e.g., [120,121]), improved efficiency (e.g., [122]), and renewable energy expansion (e.g., [123,124]) have 
all been shown to have limited success and unintended impacts (for overview, see [102]). Attempts to surmount the capital-climate contradiction that do not address the drive to accumulate capital will probably fail to significantly reduce emissions and, as Marcuse's critical theory of capitalism would predict, will conceal, rather than address, the contradiction [102,125].

It is only in this political-economic context that arguments supporting geoengineering acquire any validity and, we predict, will continue to gain traction. Geoengineering, as a distinct kind of strategy to conceal the capital-climate contradiction, may be in conflict with the prominent mitigation strategies described above in the sense that geoengineering may lessen the motivation to reduce emissions by diminishing their negative impacts, thereby undermining the potential monetary gains of those banking on "green growth". We cannot predict if the interests of those with stakes in these different paths to climate-related profit-making will conflict or cooperate in the future. Regardless, geoengineering is related to established mitigation strategies in at least two ways: (1) the frustration resulting from the latter's relative failure underpins the case for geoengineering [41] and, (2) as explained in this subsection, geoengineering, like the greening of technology and markets, is a response to the capital-climate contradiction that masks and reproduces, rather than addresses and moves beyond, the driving force underlying the contradiction (i.e., the drive to accumulate capital). This is especially clear in arguments concerning the "cost-effectiveness" of geoengineering and geoengineering as an accumulation strategy itself (i.e., geoengineering itself can generate profits). Illustrating Marcuse's description of economic rationality, monetary and cost-benefit reasoning has dominated arguments in support of geoengineering from early on, even among scientists [8]. For example, deceased hydrogen bomb scientist Edward Teller claimed that geoengineering approaches would only cost $\$ 100$ million or $\$ 1$ billion a year compared to the $\$ 100$ billion a year estimated to reduce fossil fuel usage to address "a problem that may not exist" [126]. According to Crutzen [78], SAI approaches would cost about $\$ 25-50$ billion per year, over 100 times less expensive than emissions reduction [127]. As stated by the two leading scientists and dominant voices in current geoengineering discussions, Caldeira and Keith [128] (p. 57), "geoengineering could be the only affordable and fast-acting option to avoid a global catastrophe". Compared to other approaches, SAI is especially being touted as a cheap and easy fix for climate change, and while the exact costs are still uncertain, they could be in the range of $\$ 700$ million per year [81]. David Keith called SRM: "a cheap tool that could green the world" [81] (p. x).

Economists are even more explicit about geoengineering being the best choice to address climate change, further illustrating economic rationality. A panel of five leading economists organized by Bjorn Lomborg, including three Nobel Prize winners, ranked the best ways to address climate change: increasing cloud reflection was ranked first with reducing carbon emissions ranked twelfth [79]. Economists Bickel and Lane [129] concluded that the benefits outweigh the costs of geoengineering: every dollar spent on SAI will yield \$25. The authors of the book Superfreakonomics [130], a popular book on economics for the general public, also argued that lowering carbon emissions is too costly and too complex in comparison to SRM-a cheaper and simpler plan. In short, these geoengineering strategies represent a simple, lower cost alternative to reducing GHG emissions: the economics of geoengineering are "incredible" [131].

Despite claims of cheapness, projections of SAI cost-effectiveness tend to ignore the costs of potential side-effects [8]. Most figures include only operational costs, ignoring the external costs or side-effects related to deployment that would likely vary regionally, could be catastrophic (e.g., significantly reduce crop yields), and are impossible to predict [132]. Furthermore, while geoengineering proponents claim that aggressively reducing GHG emissions would have devastating impacts on the global economy, the IPCC [133] predicts that waiting longer to implement mitigation actions will result in greater economic losses in the future.

The sociological issue, however, is more subtle than the validity of the problematic cost-effectiveness justification. The issue is that profit-maximization is the only "argument" that really matters in capitalist societies and consistently overrides other values and possibilities. In addition to its assumed cost-effectiveness, geoengineering represents an accumulation strategy, i.e., it represents 
a way to address climate change while supporting business investments and economic growth. Despite a lack of government funding [97], investments are already increasing in geoengineering technology. Entrepreneurs and companies have patented geoengineering technologies in hopes of future returns on their investments, setting up a trajectory for deployment [80]. Long and Scott [134] raised some important questions about the vested interests in geoengineering research, highlighting how individuals (e.g., Bill Gates) and companies who have invented geoengineering technologies may try to manipulate policy decision-making processes in order to make money. In addition, companies may suppress studies with findings contrary to their best interests, use questionable methods, or misrepresent information. Geoengineering could become an industry similar to biotechnology, where companies advertise humanitarian goals, while profiting from innovations that may pose serious risks to society. While governmental bodies will likely make the ultimate decisions whether to implement specific geoengineering strategies, those with financial interests could attempt to sway the decision-making process in their favor.

This subsection provided three reasons that the rationality used to make the case for the potential future deployment of geoengineering strategies "incorporate" the value of capital's necessary self-expansion, a central claim in the critical theory of technology. First, the emergence of geoengineering as a climate change strategy, especially those that are highly risky, makes sense only in a political-economic context that is structurally incapable of reducing GHG emissions through the contraction of economic growth. That is, geoengineering is rooted in a "pregiven reality": an ecologically destructive social formation likely incapable of overcoming the capital-climate contradiction. Second, a common case for geoengineering strategies, especially SAI, is that it is much cheaper than GHG emissions reductions. Third, geoengineering is already being explored as an accumulation strategy, or, as a means to make money.

\subsection{Geoengineering Would Be a Techno-Scientific Achievement}

"Contemporary positivism ... define[s] and filter[s] the universe of discourse for the use of technicians, specialists, and experts who calculate, adjust, and match without ever asking for whom or for what. The occupation of these specialists is to make things work, but not to give an end to this process."

-Herbert Marcuse [63] (p. 122)

Although proponents of geoengineering are uneasy about their support [10], many proponents, including scientists, have directly stated or indicated that geoengineering would represent an exciting and groundbreaking scientific achievement. Astrophysicist Lowell Wood, a strong and vocal proponent of geoengineering, stated, "[w] $\mathrm{e}^{\prime}$ ve engineered every other environment we live in- why not the planet?" (quoted in [135]). In his recent book on SRM, David Keith [81] (pp. 173-174) declared that, "[w]e may use these powers for good or ill, but it is hard not to delight in these newfound tools". The development of geoengineering technology represents the advancement of scientific achievement and progress. Even with the great number of possible risks, some scientists argue that the only way to proceed is with larger scale testing and eventual deployment [80,81], with one stating, "we don't know how to ride a bicycle when we start, but we end up doing it" (quoted in [79], p. 179). The quotes in this section illustrate notions of mastery (total control) over a mechanical universe (technological rationality).

Those promoting and funding geoengineering are often techno-optimists who believe that the human race can invent its way out of problems. For example, David Keith argued that humans have a long history of successfully using techno-fixes to address problems and suggests SRM is the next big techno-fix [81]. In addition, Bill Gates is the world's leading financial supporter of geoengineering innovations and is known for viewing climate change as a technical problem that can be fixed through innovation. He provides money for a research fund run by Caldeira and Keith and has invested in geoengineering technology through companies: Silver Lining, Carbon Engineering Ltd., and Intellectual ventures [80]. Gates also has his name on at least one geoengineering patent. He has 
dismissed or belittled approaches relying on renewable energy, calling these strategies "cute" with solar power being the "cutest" [136], and supports efforts to discover technological breakthroughs that will transform our relationship with the climate [137]. For Gates and other techno-optimists, society can address climate change simply through identifying and developing the appropriate high-tech fixes.

Beyond using geoengineering as a techno-fix to change nature, to some proponents it represents a way for humans to use technology to wholly master nature. Scientists have long sought out techno-fixes to alter the environment, looking for levers that can be switched to change nature [65]. In his 2013 book, David Keith [81] repeatedly framed SRM as ultra-powerful leverage over the climate. To some, geoengineering represents the ultimate trump card. In newspapers, 46 percent of articles frame geoengineering as a techno-fix or quick fix, allowing humans to change nature [43]. Overall, talk among scientists, captured by journalists and authors, indicates that many frame geoengineering in a language of techno-glorification. It has been equated with using "eco-judo" and as a way to "play god" $[43,79,80]$. Scientists and entrepreneurs are also discussing moving beyond geoengineering as a way to address climate change, exploring how they can use geoengineering technology to tailor the climate to optimal conditions [80].

Dominant portrayals of geoengineering in the media indicate that it is seen as a simple application of technology to control a mechanistic system. Research on the use of metaphors offers a means to understand how geoengineering is viewed among scientists and journalists and how these messages are being transferred to the public. Metaphor usage indicates that the planet is viewed as a machine and geoengineering as a useful tool to fix or control the machine [40]. Using medical metaphors, geoengineering has been called sunscreen for the planet [126], a cure for a sick planet, chemotherapy for the planet, liposuction for the planet, and an ice bath for a raging fever $[40,79]$. These statements indicate that geoengineering is seen as a logical tool to address the problem of climate change. They also illustrate reductionist thinking applied to a highly complex and unpredictable system.

The notion of technological rationality developed by Marcuse and Feenberg can help explain why geoengineering schemes are taken seriously among some policy makers and scientists. Or, stated differently, one can hypothesize why more substantive and even radical social alternatives are not. Geoengineering schemes exemplify technological rationality's reduction of nature to "stuff of control and organization" [1] (p. 153) in order to control the natural world through "classification, quantification, and control" [35] (p. 87). Coupled with the technological rationality used to conceive of, and justify, injecting sulfate aerosols into the stratosphere, the latter technical process itself is part of the ideological character of the geoengineering agenda, in which ideology is understood as ideas and practices that conceal real contradictions [138]. If ever set in motion, SAI would be an awesome material manifestation of the ideological masking of the capital-climate contradiction. Portrayed as a means to control nature, this process appears as a decisive techno-scientific achievement and the rational way forward. As put by Hamilton [80] (p. 174): "technologies gather added political momentum because we live in societies predisposed to seek technological answers to social problems". Many may be lured by the promise of a giant techno-fix that allows for the further mastery of nature, especially when technology is broadly understood as "the form of modern experience itself, the principal way in which the world is revealed" [35] (p. xiii). In a one-dimensional society, where technical achievements primarily serve giant industries who "deliver the goods"—and, in this case, deliver the solutions-there is a tendency to identify with the system and dominant rationality. This is what Marcuse [62] (p. 143) called the "matter of factness" attitude that inhibits forms of thinking and acting that could create a qualitatively different social formation.

Related to the repelling of social alternatives, pure technological rationality works against reflection on the goodness of ends. This is a problem in the context of climate change because, as Gardiner [139] argued, climate change is the "perfect moral storm," or, a convergence of complex global, intergenerational, and theoretical issues that makes answering and responding to ethical questions difficult, increasing susceptibility to moral corruption and inaction. In another powerful analogy borrowed from the climate scientist Gavin Schmidt, climate change is analogized as a boat being 
rocked by one traveler (polluters) and another traveler (geoengineers) "offers to use his knowledge of chaotic dynamics to try to counterbalance the first [polluters], but admits that he needs huge informational resources to do so, cannot guarantee success, and may make things worse" [33] (p. 249). Of course, the analogy is loaded, as it would be better for the "reckless, callous, and shallow" boat rocker to "just sit down" (reduce emissions) than to risk further human influence on the climate system [33] (p. 249).

Before concluding the discussion of geoengineering from the perspective of Marcuse's theory of technological rationality, Gardiner's boat rocking analogy is a helpful entry point for briefly commenting on how Marcuse can contribute to the discussion of climate ethics and the ethics of geoengineering. As stressed in this project, Marcuse helps explain why the boat rocker cannot sit down (the drive to accumulate capital), why counteracting this rocking is suggested as an alternative to sitting down (the reproduction of capital accumulation), and why this alternative is increasingly considered a viable solution to climate change (the radical instrumentalization of reason). In other words, as stressed in this project, Marcuse's primary contribution to ethical reflection about climate change and geoengineering is "negative" and sociological (i.e., placing these ethical considerations in socio-economic context and predicting that capitalist society may be structurally incapable of responding ethically). However, Marcusian thought can make positive contributions as well. Marcuse's distinction between essence and appearance (see Section 2.2) is not only analytical, but also an "ethical imperative, which states that our existence ought to conform to our essence“" [140] (p. 95). The latter entails a search for social movements and actors who may have be able to overcome the capital-climate contradiction and form a society in which humanity is able to "sit down" (reduce emissions) and be happy. Gunderson [60] (p. 231) argued that the movement to sustainably contract the economy ("degrowth") (see Section 2.1) is Marcusian in nature. Marcuse's [71] support of Third World liberation indicates that he would side with the Global South in questions of global climate justice. Further, influenced by Walter Benjamin's messianism [35] (p. 19), questions of intergenerational climate justice would be imperative for Marcuse, informed by a future-oriented analysis of what is potential in the current social order. Finally, his late work on the "new sensibility" and "new technology" (e.g., [70,71]) have applications for discussions of environmental solutions, including climate change responses [66]. While a systematic elaboration of these insights sits outside of the aims of this project, there are positive contributions to be learned from Marcuse, and critical theory more generally, in climate ethics and politics.

As stressed by Marcuse and Feenberg, economic and technological rationality are mutually reinforcing forms of instrumentality. Failure to consider the end goals and consequences, while focusing instead on technological progress and immediate economic growth, results in another instance of what Marcuse [1] (p. 9) called the most "vexing" aspect of advanced capitalism: "the rational character of its irrationality". A low-cost, industry-friendly, and high-tech solution appeals to "reason," but the use of technology to solve problems is contradictory when it does not address the root causes of problems and the technological means overshadow the ultimate outcomes, casting aside the required social changes. Further, technological rationality, because it cannot detect potential social alternatives to the current order and mitigates against ethical reflection, serves the current social order.

\section{Conclusions}

Discussions of geoengineering often focus on technical or means-oriented questions (i.e., "how" questions), overlooking the ends and interests involved. To interrogate the "whys" of geoengineering, we have applied Herbert Marcuse's theorization of the relations between technology, capitalism, rationality, and nature. This project brings substantive discussions of geoengineering forward through the following lines of argumentation: (1) geoengineering is a contradictory solution to a systemic contradiction between capital accumulation and climate stability; (2) the value of profit-maximization—or, more fundamentally, the structural drive to accumulate capital—shapes justifications for the possible deployment of geoengineering; and (3) technological rationality 
is a constitutive element of the case for geoengineering, a form of reason that aids in the reproduction of the social order (as opposed to locating alternative social futures). We argue that geoengineering-specifically SAI-supports economic priorities (and powerful financial actors), protects an inherently ecologically harmful social formation, and relegates the fundamental social-structural changes needed to actually address climate change.

Inverting our argument may clarify our thesis: emissions reductions, unlike geoengineering, are expensive, rely more on social-structural than technical changes, and are at odds with the current system (i.e., the current social system may be structurally incapable of significantly reducing emissions). Because of this, we predict that geoengineering strategies, no matter how risky, will increasingly be considered principal means to combat climate change, perhaps even as alternatives to emissions reductions. Indeed, our discussion takes on particular importance, as enthusiasm for geoengineering is increasing among high-level officials in the Trump administration and the Republican Party [141,142], and unprecedented outdoor geoengineering experiments are now moving forward [143]. The Stratospheric Controlled Perturbation Experiment, for example, which is planned to take place in early 2018 in Arizona, will represent a critical outdoor experiment for SRM researchers and will involve the launch of balloons containing up to a kilogram of aerosol particles [144].

From a critical theoretical perspective, the fact that geoengineering is "getting ever closer to the mainstream" [10] (p. xii) (see also [32]) is a clear indication of (1) capitalism's inability to overcome the capital-climate contradiction and (2) the radical instrumentalization of reason. The emergence of the geoengineering agenda is incomprehensible outside of this context. It would not make sense to inject millions of tons of sulfate aerosols into the stratosphere, for example, in a society capable of casting off growth-dependence, organizing production to meet needs, and interacting with the biophysical world in non-destructive ways. The models and techniques put forth by the geoengineering agenda are not simply ecologically and socially risky, they are, as Marcuse predicted, rooted in a vision of a nature as a set of passive resources that can be fully controlled in line with the demands of capital. Thus, we agree with others that bringing the question of capitalism to the forefront of social-environmental analysis, as opposed to assuming capitalism's naturalness or immutability, is crucial for explaining environmental harms, shedding light on unsustainable solutions to the environmental crisis, and locating more sustainable social futures [145].

When promoted as a cheap, high-tech, and market-friendly strategy due to insufficient emissions reductions, the whys of geoengineering reflect a society that transforms what should be considered means (technology and economic production) into ends themselves. Such a condition echoes the early Frankfurt School's primary thesis: instrumental rationality remains "irrational". With the proliferation of a form of reason incapable of formulating substantively rational ends, the development and spread of capitalism, and unreflective technical progress, reason has lost its aim (the emancipation of human beings), and the domination of humans and nature has become an end-in-itself. Reason remains contradictory and irrational when it endures as the "frantic development of productivity, conquest of nature, [and] enlargement of the mass of goods" [72] (p. 207).

One goal of "critique" since Hegel is to achieve "reflection on a system of constraints which are humanly produced" in order to overcome undesirable power relations [146] (p. 18). The underlying goal of this project was to shed light on the humanly produced political-economic context that gave birth to risky responses to climate change, and the forms of rationality used to justify these responses. This is the first step toward formulating rational social alternatives that do not require potentially catastrophic responses to climate change. There are likely readers who, like us, find fault in the techno-optimistic and economic justifications for geoengineering and are aware of its social and ecological risks. However, these readers may still reasonably think that geoengineering, although risky, may be our only large-scale option at some point in the future. Or, as the U.S. NRC's [5] (p. 146) report on SRM put it:

[m]itigation, although technologically feasible, has been difficult to achieve for political, economic, and social reason that may persist well into the future. ... Although there are 
ongoing efforts at climate adaptation in many communities, both humans and ecosystems face substantial challenges in adapting to the varied impacts of climate change over the coming century. For that reason, it is prudent to examine other options [i.e., geoengineering] for limiting the risks from climate change, even as mitigation and adaptation remain the primary emphasis.

However, geoengineering is a dangerous and contradictory attempt to transform the problem-the domination of nature through technology in the service of capitalism-into the solution. The drastic changes needed to reduce emissions involve fundamental changes in our social formation. If the latter course is cast off as more utopian and unrealistic than SAI, for example, perhaps Adorno [147] (pp. 107-108) was right to claim that, "[t]he horror is that for the first time we live in a world in which we can no longer imagine a better one".

Acknowledgments: The first author would like to thank Miami University's Committee on Faculty Research for their financial contribution aiding open access publishing.

Author Contributions: Diana Stuart conceived of the idea of examining the development of the geoengineering agenda through Marcuse's ideas. Ryan Gunderson integrated the theoretical framework and reviewed most of the social scientific research on geoengineering. Brian Petersen and Diana Stuart reviewed most of the literature on climate change and geoengineering strategies. All three authors participated in theory application.

Conflicts of Interest: The authors declare no conflict of interest.

\section{References}

1. Marcuse, H. One-Dimensional Man; Beacon Press: Boston, MA, USA, 1964.

2. The Royal Society. Geoengineering the Climate: Science, Governance and Uncertainty; The Royal Society: London, UK, 2009. Available online: http://eprints.soton.ac.uk/156647/1/Geoengineering_the_climate.pdf?origin= publication_detail (accessed on 16 November 2017).

3. Gardiner, S.M. Some early ethics of geoengineering the climate: A commentary on the values of the Royal Society report. Environ. Values 2011, 20, 163-188. [CrossRef]

4. Bellamy, R.; Chilvers, J.; Vaughan, N.E.; Lenton, T.M. A review of climate geoengineering appraisals. WIREs Clim. Chang. 2012, 3, 597-615. [CrossRef]

5. U.S. National Research Council. Climate Intervention: Reflecting Sunlight to Cool Earth; Committee on Geoengineering Climate: Technical Evaluation and Discussion of Impacts. Board on Atmospheric Sciences and Climate. Ocean Studies Board. Division on Earth and Life Studies; The National Academies Press: Washington, DC, USA, 2015. Available online: http://www.nap.edu/openbook.php?record_id=18988 (accessed on 17 November 2017).

6. Corner, A.; Pidgeon, N. Geoengineering the climate: The social and ethical implications. Environment 2010, 52, 24-37. [CrossRef]

7. Elliott, K. Geoengineering and the precautionary principle. Int. J. Appl. Philos. 2010, 24, 237-253. [CrossRef]

8. Gardiner, S.M. Is 'arming the future' with geoengineering really the lesser evil? Some doubts about the ethics of intentionally manipulating the climate system. In Climate Ethics: Essential Readings; Gardiner, S.M., Caney, S., Jamieson, D., Shue, H., Eds.; Oxford University Press: New York, NY, USA, 2010; pp. 284-312.

9. Preston, C.J. (Ed.) Engineering the Climate: The Ethics of Solar Radiation Management; Lexington Books: Plymouth, UK, 2012.

10. Preston, C.J. (Ed.) Climate Justice and Geoengineering: Ethics and Policy in the Atmospheric Anthropocene; Rowman \& Littlefield: London, UK, 2016.

11. Sikka, T. A critical discourse analysis of geoengineering advocacy. Crit. Discourse Stud. 2012, 9, 163-175. [CrossRef]

12. Sikka, T. A critical theory of technology applied to the public discussion of geoengineering. Technol. Soc. 2012, 34, 109-117. [CrossRef]

13. Whyte, K.P. Indigenous peoples, solar radiation management, and consent. In Engineering the Climate: The Ethics of Solar Radiation Management; Preston, C.J., Ed.; Lexington Books: Plymouth, UK, 2012; pp. 65-75.

14. Bellamy, R.; Chilvers, J.; Vaughan, N.E.; Lenton, T.M. 'Opening up' geoengineering appraisal: Multi-criteria mapping of options for tackling climate change. Glob. Environ. Chang. 2013, 23, 926-937. [CrossRef] 
15. Burns, W.C.G.; Strauss, A.L. (Eds.) Climate Change Engineering: Philosophical Perspectives, Legal Issues, and Governance Frameworks; Urizen Books: New York, NY, USA, 2013.

16. Macnaghten, P.; Szerszynski, B. Living the global social experiment: An analysis of public discourse on solar radiation management and its implications for governance. Glob. Environ. Chang. 2013, 23, 465-474. [CrossRef]

17. Szerszynski, B.; Kearnes, M.; Macnaghten, P.; Owen, R.; Stilgoe, J. Why solar radiation management geoengineering and democracy won't mix. Environ. Plan. A 2013, 45, 2809-2816. [CrossRef]

18. Healey, P. The Stabilisation of Geoengineering: Stabilising the Inherently Unstable? Geoengineering Governance Research, Working Paper Series 015; Institute for Science, Innovation and Society, University of Oxford, 2014. Available online: http:/ / www.geoengineering-governance-research.org/cgg-working-papers. php (accessed on 18 January 2018).

19. Hulme, M. Can Science Fix Climate Change?: A Case against Climate Engineering; Polity: Malden, MA, USA, 2014.

20. Owen, R. Solar radiation management and the governance of hubris. In Geoengineering of the Climate System; Harrison, R., Hester, R., Eds.; Royal Society of Chemistry: London, UK, 2014.

21. Burns, W.C.; Flegal, J.A. Climate geoengineering and the role of public deliberation: A comment on the US National Academy of Sciences' recommendations on public participation. Clim. Law 2015, 5, 252-294.

22. US National Research Council. Climate Intervention: Carbon Dioxide Removal and Reliable Sequestration; Committee on Geoengineering Climate: Technical Evaluation and Discussion of Impacts. Board on Atmospheric Sciences and Climate. Ocean Studies Board. Division on Earth and Life Studies; The National Academies Press: Washington, DC, USA, 2015. Available online: http:/ /www.nap.edu/openbook.php? record_id=18805 (accessed on 17 November 2017).

23. Payne, C.R.; Shwom, R.; Heaton, S. Public participation and norm formation for risk technology: Adaptive governance of solar-radiation management. Clim. Law 2015, 5, 210-251.

24. Stilgoe, J. Experiment Earth: Responsible Innovation in Geoengineering; Routledge: New York, NY, USA, 2015.

25. Clingerman, F.; O'Brien, K.J. (Eds.) Theological and Ethical Perspectives on Climate Engineering: Calming the Storm; Lexington Books: Lanham, MD, USA, 2016.

26. Elliot, K. Climate geoengineering. In The Argumentative Turn in Policy Analysis: Reasoning about Uncertainty; Hansson, S.O., Hadorn, G.H., Eds.; Springer: Berlin, Germany, 2016; pp. 305-324.

27. Gunderson, R. Ideology critique for the environmental social sciences: What reproduces the treadmill of production? Nat. Cult. 2017, 12, 263-289. [CrossRef]

28. Horkheimer, M. Eclipse of Reason; Continuum: New York, NY, USA, 1947.

29. $\mathrm{Ng}, \mathrm{K}$. Ideology critique from Hegel and Marx to critical theory. Constellations 2015, 22, 393-404. [CrossRef]

30. Benhabib, S. Critique, Norm, and Utopia: A Study of the Foundations of Critical Theory; Columbia University Press: New York, NY, USA, 1986.

31. Hamilton, C. The ethical foundations of climate engineering. In Climate Change Engineering: Philosophical Perspectives, Legal Issues, and Governance Frameworks; Burns, W.C.G., Strauss, A.L., Eds.; Urizen Books: New York, NY, USA, 2013; pp. 39-58.

32. Hamilton, C. Geoengineering and the politics of science. Bull. Atomic Sci. 2014, 70, 17-26. [CrossRef]

33. Gardiner, S.M. Are we the scum of the earth? Climate change, geoengineering, and humanity's challenge. In Ethical Adaptation to Climate Change: Human Virtues of the Future; Thompson, A., Bendik-Keymer, J., Eds.; MIT Press: Cambridge, MA, USA, 2012; pp. 241-260.

34. Feenberg, A. Can technology incorporate values? Marcuse's answer to the question of the age. Presented at the conference The Legacy of Herbert Marcuse, University of California: Berkeley, CA, USA, 7 November 1999. Available online: http:/ / www.sfu.ca/ andrewf/books/Can_Technology_Incorporate_ Values.pdf (accessed on 17 November 2017).

35. Feenberg, A. Heidegger and Marcuse: The Catastrophe and Redemption of History; Routledge: New York, NY, USA, 2005.

36. Corner, A.; Pidgeon, N.; Parkhill, K. Perceptions of geoengineering: Public attitudes, stakeholder perspectives \& the challenge of 'upstream' engagement. Wiley Interdiscip. Rev. Clim. Chang. 2012, 3, 451-466.

37. Corner, A.; Parkhill, K.; Pidgeon, N.; Vaughan, N.E. Messing with nature? Exploring public perceptions of geoengineering in the UK. Glob. Environ. Chang. 2013, 23, 938-947. [CrossRef]

38. Pidgeon, N.; Corner, A.; Parkhill, K.; Spence, A.; Butler, C.; Poortinga, W. Exploring early public responses to geoengineering. Philos. Trans. R. Soc. 2012, 370, 4176-4196. [CrossRef] [PubMed] 
39. Corner, A.; Parkhill, K.A.; Pidgeon, N. Experiment Earth?: Reflections on a Public Dialogue on Geoengineering. Understanding Risk; Working Paper 11-02; School of Psychology, Cardiff University: Cardiff, UK, 2011.

40. Nerlich, B.; Jaspal, R. Metaphors we die by? Geoengineering, metaphors, and the argument from catastrophe. Metaphor Symbol 2012, 27, 131-147. [CrossRef]

41. Bellamy, R. Framing geoengineering assessment. Geoengineering Our Climate. Working Paper and Opinion Articles Series. 2013. Available online: http:/ / wp.me/p2zsRk-9H (accessed on 17 November 2017).

42. Markusson, N. Tensions in Framings of Geoengineering: Constitutive Diversity and Ambivalence. Climate Geoengineering Governance Working Paper Series 003; Institute for Science, Innovation and Society, University of Oxford, 2013. Available online: http:/ / www.geoengineering-governance-research.org/cggworking-papers.php (accessed on 18 January 2018).

43. Scholte, S.; Vasileiadou, E.; Petersen, A.C. Opening up the social debate on climate engineering: How newspaper frames are changing. J. Integr. Environ. Sci. 2013, 10, 1-16. [CrossRef]

44. Luokkanen, M.; Huttunen, S.; Hildén, M. Geoengineering, news media and metaphors: Framing the controversial. Public Underst. Sci. 2014, 23, 966-981. [CrossRef] [PubMed]

45. Muraca, B.; Neuber, F. Viable and convivial technologies: Considerations on Climate Engineering from a degrowth perspective. J. Clean. Prod. 2017. [CrossRef]

46. Martinez-Alier, J.; Healy, H.; Temper, L.; Walter, M.; Rodriguez-Labajos, B.; Gerber, J.F.; Conde, M. Between science and activism: Learning and teaching ecological economics with environmental justice organisations. Local Environ. 2011, 16, 17-36. [CrossRef]

47. Videira, N.; Schneider, F.; Sekulova, F.; Kallis, G. Improving understanding on degrowth pathways: An exploratory study using collaborative causal models. Futures 2014, 55, 58-77. [CrossRef]

48. Weiss, M.; Cattaneo, C. Degrowth-Taking stock and reviewing an emerging academic paradigm. Ecol. Econ. 2017, 137, 220-230. [CrossRef] [PubMed]

49. Georgescu-Roegen, N. Feasible recipes and viable technologies. Atl. Econ. J. 1984, 12, 21-30. [CrossRef]

50. Illich, I. Tools for Conviviality; Harper \& Row: New York, NY, USA, 1973.

51. Hale, B. The world that would have been: Moral hazard arguments against geoengineering. In Engineering the Climate: The Ethics of Solar Radiation Management; Preston, C.J., Ed.; Lexington Books: Plymouth, UK, 2012; pp. 113-131.

52. Schäfer, S.; Stelzer, H.; Maas, A.; Lawrence, M.G. Earth's future in the Anthropocene: Technological interventions between piecemeal and Utopian social engineering. Earth's Future 2014, 2, 239-243. [CrossRef]

53. Entman, R.M. Framing: Toward clarification of a fractured paradigm. J. Commun. 1993, 43, 51-58. [CrossRef]

54. Marcuse, M. The concept of essence. In Negations; Beacon Press: Boston, MA, USA, 1968; pp. $43-87$.

55. Cohen, J. Critical theory: The philosophy of Marcuse. New Left Rev. 1969, 57, 35-59.

56. Held, D. Introduction to Critical Theory: Horkheimer to Habermas; University of California Press: Berkeley, CA, USA, 1980.

57. Marcuse, H. Eros and Civilization: A Philosophical Inquiry into Freud; Vintage Books: New York, NY, USA, 1955.

58. Kellner, D. Critical Theory, Marxism and Modernity; Johns Hopkins University Press: Baltimore, MD, USA, 1989.

59. Horkheimer, M.; Adorno, T.W. Dialectic of Enlightenment; Continuum: New York, NY, USA, 1969.

60. Gunderson, R. Environmental sociology and the Frankfurt School 1: Reason and capital. Environ. Sociol. 2015, 1, 224-235. [CrossRef]

61. Adorno, T.W. Critical Models: Interventions and Catchwords; Columbia University Press: New York, NY, USA, 1998.

62. Marcuse, H. Some social implications of modern technology. In The Essential Frankfurt School Reader; Arato, A., Gebhardt, E., Eds.; Urizen Books: New York, NY, USA, 1978; pp. 138-162.

63. Marcuse, H. From ontology to technology: Fundamental tendencies of industrial society. In Critical Theory and Society; Bronner, S.E., Kellner, D., Eds.; Routledge: New York, NY, USA, 1989; pp. 119-127.

64. Marcuse, H. On science and phenomenology. In Philosophy, Psychoanalysis and Emancipation: Collected Papers of Herbert Marcuse, Volume 5; Kellner, D., Pierce, C., Eds.; Routledge: New York, NY, USA, 2011; pp. 145-155.

65. Marcuse, $\mathrm{H}$. The problem of social change in the technological society. In Towards a Critical Theory of Society: Collected Papers of Herbert Marcuse, Volume 2; Kellner, D., Pierce, C., Eds.; Routledge: New York, NY, USA, 2001; pp. 37-54.

66. Gunderson, R. Environmental sociology and the Frankfurt School 2: Ideology, techno-science, reconciliation. Environ. Soc. 2016, 2, 64-76. [CrossRef] 
67. Feenberg, A. Marcuse or Habermas: Two critiques of technology. Inquiry 1996, 39, 45-70. [CrossRef]

68. Feenberg, A. Questioning Technology; Routledge: New York, NY, USA, 1999.

69. Feenberg, A. Critical theory of technology: An overview. Tailoring Biotechnol. 2005, 1, 47-64.

70. Marcuse, H. Counterrevolution and Revolt; Beacon Press: Boston, MA, USA, 1972.

71. Marcuse, H. An Essay on Liberation; Beacon Press: Boston, MA, USA, 1969.

72. Marcuse, H. Industrialization and capitalism in Max Weber. In Negations; Beacon Press: Boston, MA, USA, 1968; pp. 201-226.

73. The Frankfurt Institute of Social Research. Aspects of Sociology; Beacon Press: Boston, MA, USA, 1972.

74. Marcuse, H. The responsibility of science. In Philosophy, Psychoanalysis and Emancipation: Collected Papers of Herbert Marcuse, Volume 5; Kellner, D., Pierce, C., Eds.; Routledge: New York, NY, USA, 2011; pp. 155-159.

75. Hornborg, A. Artifacts have consequences, not agency: Toward a critical theory of global environmental history. Eur. J. Soc. Theory 2017, 20, 95-110. [CrossRef]

76. Intergovernmental Panel on Climate Change. 2013. Summary for policymakers. In Climate Change 2013: The Physical Science Basis; Stocker, T.F., Qin, D., Plattner, G.-K., Tignor, M., Allen, S.K., Boschung, J., Nauels, A., Xia, Y., Bex, V., Midgley, P.M., Eds.; Contribution of Working Group I to the Fifth Assessment Report of the Intergovernmental Panel on Climate Change; Cambridge University Press: Cambridge, UK; New York, NY, USA, 2013.

77. Hansen, J.; Sato, M.; Kharecha, P.; Beerling, D.; Berner, R.; Masson-Delmotte, V.; Pagani, M.; Raymo, M.; Royer, D.L.; Zachos, J.C.; et al. Target atmospheric $\mathrm{CO}_{2}$ : Where should humanity aim? Open Atmos. Sci. J. 2008, 2, 217-231. [CrossRef]

78. Crutzen, P.J. Albedo enhancement by stratospheric sulfur injections: A contribution to resolve a policy dilemma? Clim. Chang. 2006, 77, 211-219. [CrossRef]

79. Kintisch, E. Hack the Planet: Science's Best Hope-Or Worst Nightmare-For Averting Climate Catastrophe; John Wiley \& Sons: Hoboken, NJ, USA, 2010.

80. Hamilton, C. Earthmasters: The Dawn of the Age of Climate Engineering; Yale University Press: Padstow, PA, USA, 2013.

81. Keith, D.W. A Case for Climate Engineering; MIT Press: Boston, MA, USA, 2013.

82. Fleming, J.R. Fixing the Sky: The Checkered History of Weather and Climate Control; Columbia University Press: New York, NY, USA, 2010.

83. Boucher, O.; Randall, D.; Artaxo, P.; Bretherton, C.; Feingold, G.; Forster, P.; Kerminen, V.-M.; Kondo, Y.; Liao, H.; Lohmann, U.; et al. Clouds and aerosols. In Climate Change 2013: The Physical Science Basis; Stocker, T.F., Qin, D., Plattner, G.-K., Tignor, M., Allen, S.K., Boschung, J., Nauels, A., Xia, Y., Bex, V., Midgley, P.M., Eds.; Contribution of Working Group I to the Fifth Assessment Report of the Intergovernmental Panel on Climate Change; Cambridge University Press: Cambridge, UK; New York, NY, USA, 2013.

84. Zhang, Z.; Moore, J.C.; Huisingh, D.; Yongzin, Z. Review of geoengineering approaches to mitigating climate change. J. Clean. Prod. 2015, 103, 898-907. [CrossRef]

85. Robock, A.; Bunzl, M.; Kravitz, B.; Stenchikov, G.L. A test for geoengineering? Science 2010, 327, 530-531. [CrossRef] [PubMed]

86. Weisenstein, D.K.; Kieth, D.W.; Dykema, J.A. Solar geoengineering using solid aerosol in stratosphere. Atmos. Chem. Phys. 2015, 15, 11835-11859. [CrossRef]

87. Dykema, J.A.; Keith, D.W.; Keutsch, F.N. Improved aerosol radiative properties as a foundation for solar geoengineering risk assessment. Geophys. Res. Lett. 2016, 43, 7758-7766. [CrossRef]

88. Biello, D. Can geoengineering save the world from global warming? Sci. Am. 2011. Available online: http:/ / www.scientificamerican.com/article/geoengineering-to-save-the-world-from-global-warming/ (accessed on 17 November 2017).

89. Robock, A. Geoengineering: It's not a panacea. Geotimes 2008, 53. Available online: http://www.geotimes. org/july08/article.html?id=comment.html\#robock (accessed on 17 November 2017).

90. Kieth, D.W.; MacMartin, D. A temporary, moderate and responsive scenario for solar geoengineering. Nat. Clim. Chang. 2015, 5, 201-206. [CrossRef]

91. Ferraro, A.J.; Highwood, E.J.; Charlton-Perez, A.J. Weakened tropical circulation and reduced precipitation in response to geoengineering. Environ. Res. Lett. 2014, 9, 014001. [CrossRef]

92. Robock, A. 20 reasons why geoengineering may be a bad idea. Bull. At. Sci. 2008, 64, 14-18. [CrossRef] 
93. Robock, A.; Marquardt, A.; Kravitz, B.; Stenchikov, G. Benefits, risks, and costs of stratospheric geoengineering. Geophys. Res. Lett. 2009, 36, 1-9. [CrossRef]

94. Effiong, U.; Neitzel, R.L. Assessing the direct occupational and public health impacts of solar radiation management with stratospheric aerosols. Environ. Health 2016, 15, 7. [CrossRef] [PubMed]

95. Nowack, P.J.; Abraham, N.L.; Braesicke, P. Stratospheric ozone changes under solar geoengineering: Implications for UV exposure and air quality. Atmos. Chem. Phys. 2016, 16, 4191-4203. [CrossRef]

96. McCusker, K.E.; Armour, K.C.; Bitz, C.M.; Battisti, D.S. Rapid and extensive warming following cessation of Solar Radiation Management. Environ. Res. Lett. 2014, 9, 024005. [CrossRef]

97. Long, J.C.S.; Loy, F.; Morgan, M.G. Start research on climate engineering. Nature 2015, 518, 29-31. [CrossRef] [PubMed]

98. Hamilton, C. No, we should not just 'at least do the research'. Nature 2013, 496, 139. [CrossRef] [PubMed]

99. Stilgoe, J. Geoengineering as collective experimentation. Sci. Eng. Ethics 2016, 22, 851-869. [CrossRef] [PubMed]

100. Weis, T. The accelerating biophysical contradictions of industrial capitalist agriculture. J. Agrar. Chang. 2010, 10, 315-341. [CrossRef]

101. Wright, C.; Nyberg, D. Climate Change, Capitalism, and Corporations: Processes of Creative Self-Destruction; Cambridge University Press: Cambridge, UK, 2015.

102. Gunderson, R.; Stuart, D.; Petersen, B. Ideological obstacles to effective climate policy: The greening of markets, technology, and growth. Cap. Class 2017. [CrossRef]

103. O'Connor, J. Natural Causes: Essays in Ecological Marxism; Guilford Press: New York, NY, USA, 1998.

104. Schnaiberg, A. The Environment: From Surplus to Scarcity; Oxford University Press: New York, NY, USA, 1980.

105. Gould, K.A.; Pellow, D.N.; Schnaiberg, A. Interrogating the treadmill of production: Everything you wanted to know about the treadmill but were afraid to ask. Org. Environ. 2004, 17, 296-316. [CrossRef]

106. Antonio, R.J.; Clark, B. The climate change divide in social theory. In Climate Change and Society: Sociological Perspectives; Dunlap, R.E., Brulle, R.J., Eds.; Oxford University Press: New York, NY, USA, 2015.

107. Bryant, R.L. Power, knowledge and political ecology in the third world: A review. Progr. Phys. Geogr. 1998, 22, 79-94. [CrossRef]

108. Prudham, S. Poisoning the well: Neoliberalism and the contamination of municipal water in Walkerton, Ontario. Geoforum 2004, 35, 343-359. [CrossRef]

109. Petersen, B.; Stuart, D. Explanations of a changing landscape: A critical examination of the British Columbia bark beetle epidemic. Environ. Plan. A 2014, 46, 598-613. [CrossRef]

110. Anderson, K.; Bows, A. Beyond 'dangerous' climate change: Emission scenarios for a new world. Philos. Trans. R. Soc. Lond. A Math. Phys. Eng. Sci. 2011, 369, 20-44. [CrossRef] [PubMed]

111. Jorgenson, A.; Clark, B. Are the economy and the environment decoupling? A comparative international study, 1960-2005. Am. J. Soc. 2012, 118, 1-44. [CrossRef]

112. Kallis, G. Radical dematerialization and degrowth. Philos. Trans. R. Soc. A 2017, 375, 20160383. [CrossRef] [PubMed]

113. Hickel, J. Clean energy won't save us—only a new economic system can. The Guardian, 2015. Available online: https:/ / www.theguardian.com/global-development-professionals-network/2016/jul/15/cleanenergy-wont-save-us-economic-system-can (accessed on 5 January 2018).

114. Dunlap, R.E.; McCright, A.M. Challenging climate change: The denialist countermovement. In Climate Change and Society: Sociological Perspectives; Dunlap, R.E., Brulle, R.J., Eds.; Oxford University Press: New York, NY, USA, 2015.

115. Organization for Economic Co-operation and Development. Towards Green Growth; OECD: Paris, France, 2011.

116. Jacobs, M. Green growth. In Handbook of Global Climate and Environmental Policy; Falkner, R., Ed.; Wiley-Blackwell: Malden, MA, USA, 2013.

117. United Nations Environment Programme. Towards a Green Economy: Pathways to Sustainable Development and Poverty Eradication. 2011. Available online: http://web.unep.org/greeneconomy/ sites/unep.org.greeneconomy / files / field/image/green_economyreport_final_dec2011.pdf (accessed on 23 December 2017).

118. Association of Academies of Sciences in Asia. Towards a Sustainable Asia: Green Transition and Innovation; Science Press/Springer: Beijing, China, 2011. 
119. Dale, G.; Mathai, M.V.; de Oliveira, J.A.P. (Eds.) Green Growth: Ideology, Political Economy and the Alternatives; Zed Books: London, UK, 2016.

120. Foster, J.B.; Clark, B.; York, R. The Midas effect: A critique of climate change economics. Dev. Chang. 2009, 40, 1085-1097. [CrossRef]

121. Stuart, D.; Gunderson, R.; Petersen, B. Climate Change and the Polanyian Counter-movement: Carbon Markets or Degrowth? New Political Econ. 2017. [CrossRef]

122. York, R.; McGee, J.A. Understanding the Jevons paradox. Environ. Soc. 2016, 2, 77-87. [CrossRef]

123. York, R. Do alternative energy sources displace fossil fuels? Nat. Clim. Chang. 2012, 2, 441-443. [CrossRef]

124. York, R. Decarbonizing the energy supply may increase energy demand. Soc. Dev. 2016, 2, $265-273$. [CrossRef]

125. Foster, J.B. Why ecological revolution? Mon. Rev. 2010, 61. Available online: http://monthlyreview.org/ 2010/01/01/why-ecological-revolution/ (accessed on 23 December 2017). [CrossRef]

126. Teller, E. Sunscreen for Planet Earth. In Hoover Digest; Hoover Institution: Stanford, CA, USA, 1998.

127. Keith, D.W. Photophoretic levitation of engineered aerosols for geoengineering. Proc. Natl. Acad. Sci. USA 2010, 107, 16428-16431. [CrossRef] [PubMed]

128. Caldeira, K.; Keith, D.W. The need for climate engineering research. Issues Sci. Technol. 2010, 27, 57-62.

129. Bickel, J.E.; Lane, L. An Analysis of Climate Engineering as a Response to Climate Change; Copenhagen Consensus Center: Frederiksberg, Denmark, 2009.

130. Levitt, S.D.; Dubner, S.J. Superfreakonomics: Global Cooling, Patriotic Prostitutes, and Why Suicide Bombers Should Buy Life Insurance; HarperCollins: New York, NY, USA, 2011.

131. Barrett, S. The incredible economics of geoengineering. Environ. Resour. Econ. 2008, 39, 45-54. [CrossRef]

132. Klepper, G.; Rickels, W. The real economics of climate engineering. Econ. Res. Int. 2012. Available online: http:/ / dx.doi.org/10.1155/2012/316564.. [CrossRef]

133. Intergovernmental Panel on Climate Change. Summary for policymakers. In Climate Change 2014: Mitigation of Climate Change; Edenhofer, O., Pichs-Madruga, R., Sokona, Y., Farahani, E., Kadner, S., Seyboth, K., Adler, A., Baum, I., Brunner, S., Eickemeier, P., et al., Eds.; Contribution of Working Group III to the Fifth Assessment Report of the Intergovernmental Panel on Climate Change; Cambridge University Press: Cambridge, UK; New York, NY, USA, 2014. Available online: http:/ / www.ipcc.ch/pdf/assessment-report/ ar5/wg3/ipcc_wg3_ar5_summary-for-policymakers.pdf (accessed on 17 November 2017).

134. Long, J.C.S.; Scott, D. Vested interests and geoengineering research. Issues Sci. Technol. 2013, $29,45-52$.

135. Hamilton, C. Geoengineering: Our last hope, or a false promise? The New York Times, 2013. Available online: http:/ / www.nytimes.com/2013/05/27/opinion/geoengineering-our-last-hope-or-a-false-promise. html (accessed on 17 November 2017).

136. Romm, J. Bill Gates disses energy efficiency, renewables, and near-term climate action while embracing the magical thinking of Bjorn Lomborg (and George Bush). Think Progress, 2010. Available online: http://thinkprogress.org/climate/2010/01/26/205380/bill-gates-energy-efficiency-insulationrenewables-and-global-climate-action-bjorn-lomborg/ (accessed on 17 November 2017).

137. Romm, J. Pro-geoengineering Bill Gates disses efficiency, 'cute' solar, deployment-Still doesn't know how he got rich'. Think Progress, 2011. Available online: http:/ / thinkprogress.org/climate/2011/05/05/208032/ bill-gates-efficiency-cute-solar/ (accessed on 17 November 2017).

138. Larrain, J. The Concept of Ideology; Hutchinson \& Co.: London, UK, 1979.

139. Gardiner, S.M. A perfect moral storm: Climate change, intergenerational ethics and the problem of moral corruption. Environ. Values 2006, 15, 397-413. [CrossRef]

140. Fraser, I. Herbert Marcuse: Essence and existence. In Marxism's Ethical Thinkers; Wilde, L., Ed.; Palgrave Macmillan: London, UK, 2001.

141. Lukacs, M. Trump presidency 'opens door' to planet-hacking geoengineer experiments. The Guardian, 2017. Available online: https:/ / www.theguardian.com/environment/true-north/2017/mar/27/trumppresidency-opens-door-to-planet-hacking-geoengineer-experiments (accessed on 17 November 2017).

142. Temple, J. GOP Embraces Geoengineering. MIT Technology Review, 2017. Available online: https: / www.technologyreview.com/the-download/609431/gop-embraces-geoengineering-whichterrifies-geoengineering-researchers/ (accessed on 17 November 2017). 
143. Connolly, K. Geoengineering is not a quick fix for climate change, experts warn Trump. The Guardian, 2017. Available online: https:/ / www.theguardian.com/environment/2017/oct/14/geoengineering-is-nota-quick-fix-for-climate-change-experts-warn-trump (accessed on 17 November 2017).

144. Chen, S. Helping Hand or Hubris? APS News, 2017. Available online: https://www.aps.org/publications / apsnews /201710/hand-hubris.cfm (accessed on 17 November 2017).

145. Longo, S.B.; Clark, B.; Shriver, T.E.; Clausen, R. Sustainability and environmental sociology: Putting the economy in its place and moving toward an integrative socio-ecology. Sustainability 2016, 8, 437. [CrossRef]

146. Connerton, P. (Ed.) Critical Sociology; Penguin Books: New York, NY, USA, 1976.

147. Adorno, T.W.; Horkheimer, M. Towards a New Manifesto; Verso: New York, NY, USA, 2011.

(C) 2018 by the authors. Licensee MDPI, Basel, Switzerland. This article is an open access article distributed under the terms and conditions of the Creative Commons Attribution (CC BY) license (http://creativecommons.org/licenses/by/4.0/). 